\title{
The Role of Medical Social Work to Raise awareness of Prevention of The Epidemic Diseases (COVID19)
}

\author{
Dr . Amal Ramadan AbdElhalim \\ Phd in social work \\ Work at, Public health and tropical medicine \\ Health education and promotion (www.iau.edu.sa ) \\ Jazan university (www.jazanu.edu.sa)
}

\begin{abstract}
:
Social work has long been viewed as an important determinant of prevention with epidemic disease, especially in times of crisis, Yet evidence on this relationship remains scarce, particularly in the developing world. We addressed that by studying examined the role of medical social work to raise awareness of prevention of the epidemic diseases, This is an analytical descriptive cross-section study .It was conducted among social workers Saudis consumers (102). It aimed at the extent of the social worker's knowledge of the nature of epidemic diseases. and determine the actual preventive role of social workers in raising awareness of preventive diseases. The hypothesis is the presence of significant interrelation between them. Non-probability convenient sampling was applied; a self-administered questionnaire was developed during the 2020 COVID20 Virus, tested and filled by 102 males and females social workers, Findings showed that the total weights and percentage social worker knowledge of epidemic diseases dimension is (3022), (89.70\%) respectively and the social worker role in raising awareness of preventive diseases dimension (3309), (83.2\%) respectively was strongly positively associated with compliance among our respondents, in addition the study noted in the relationship between socio-demographic background and dimensions of the study $\mathrm{T}$ value is insignificant at the 0.05 level (2-tailed) (Age, experience, sex , marital statues and residence).
\end{abstract}

Key words (medical social work -social worker -awareness -prevention -epidemic diseases -jazan )

\section{Introduction}

Social work has long been viewed as an important determinant of prevention with epidemic disease, especially in times of crisis. this study aimed at investigating the social worker role that predicts the onset of to raise awareness of prevention of the epidemic The research question was how much the role of social worker would predict the raise awareness of prevention of the epidemic diseases ? its measurable objectives were: 1-Determine the socio-demographic background of the study 2-The extent of the social worker knowledge of the nature of epidemic diseases. 3.Determine the actual preventive role of social workers in raising awareness of preventive diseases

Social work seeks to improvement of living and working conditions in the community, the relief or prevention of distress whether individual or social in origin according to quote from the prospectus of the New York School, ( Abraham Flexner 2010) makers can plan their health infrastructure in macro-level and pay more attention to health care prevention than treatment. Due to the increasing number of patients in the community, using social workers can find the roots of illnesses and social problems in team working.

this means that social workers use their unique techniques including community-based work, social objectives and the implementation of health programs based on community needs (Samadi Rad, 2012)., in addition, social workers across the continuum of treatment services (outpatient, acute, chronic, crisis intervention, counseling, advocacy, and case management) will play their role. Participation in natural 
disasters, global and national challenges and stress inflicted on patients and their families are the major roles that social workers can be involved in it (NASW, 2005).

\section{Research Purposes}

The purpose of this study includes:
A. Determine the socio-demographic background of the study
B. The extent of the social worker knowledge of epidemic diseases.
C. Determine the actual preventive role of social workers in raising awareness of preventive diseases

\section{Professional Social Work}

Social work as a profession commonly is known in England for a long time years ago (Samadi Rad, 2008). In 2007 the International Association of Social Workers has accepted the following definition of social work: "Professional social work, social change, problem-solving in human relationships, empowerment, and liberation of people to enhance well-being and promotes development. Using theories of human behavior and social systems, social work intervenes at the points where people interact with their environment is. Human rights and social justices are the principles and foundations of Social Work » (IFSW, cited in Wilson, Ruch, Lymbery \& Cooper, 2008). Social work has different aspects and includes a sophisticated analysis of the individual and the environment in human behavior (Hutchison E, 2008). The following is an attempt to define the meaning and purpose of their integration in social work: "Social work is trying to get through to those who do not have the right to earn a living and help to achieve the highest degree of autonomy» (Journal of Social Science for Policy Implications,2014) Thus the material presented can be concluded that social work is the professional service or services or special activity that is based on specific knowledge and skills, the purpose of the assistance to individuals, groups or society to deal more effectively with the problems they are facing and thus to achieve personal independence and fulfillment of personal or social to prevent themselves from health or social problem.

\section{Prevention and Social Work}

Prevention science is an interdisciplinary endeavor involving five distinct and interrelated phases of research related to prevention practice (Mrazek \&Haggerty, 1996):

- Epidemiology — understanding the prevalence in time and space of well-being and its

- predictors and of problems and their predictors.

- Etiology - understanding what causes positive or negative health and behavior outcomes (Delbert S. Elliott, Sharon Mihalic2004)

- through qualitative studies, longitudinal descriptive studies, and theory development.

- Efficacy trials-Designing and conducting

- trials of the effects of preventive interventions under optimal conditions (SPR, 2004).

- Effectiveness trials-Designing and conducting trials of effects of preventive interventions under real-world conditions

From ethical, scientific, and historical perspectives, prevention, and health promotion hold great promise for improving the health of society. Ethically, the case for prevention is compelling: a just society should engage in actions that can reduce suffering, disease, and death, particularly among its most vulnerable citizens (Albee, 1983). Scientifically, a considerable body of evidence has emerged demonstrating the effectiveness of prevention in diverse arenas; violence, substance abuse, homelessness, mental illness, and HIV/AIDS are issues responsive to prevention, where public health can reduce incidence prevalence, and associated harms (Cohen, Chavez \& Chehimi, 2010; Hawkins, Shapiro \& Fagan, 2010). Epidemiologists hypothesize that as many as 900,000 annual deaths are attributable to social factors, equal to the number caused by pathophysiological causes (Galea et al., 2011). These social determinants, rooted in preventable conditions, pose ongoing challenges to a profession committed to social justice. In recent years, a series of actions, articles, and undertakings within the field suggest a positive interest in prevention. A growing body of social work prevention research now exists. A working definition and competencies for public health social work-the the practice area most associated with prevention-have been developed. The National Association of Social Workers has integrated prevention into its practice standards for social workers in 
health care, and the Council on Social Work Education has included prevention in its 2008 Education Program Accreditation Standards for MSW programs The number of MSW/MPH programs is increasing, suggesting a new generation's interest in combining public health and social work (Betty J. Ruth,2016)

Alan Al-Krenawi and John R. Graham,2003.

\section{Social Workers Standards in Health Care System}

Journal of the National Association of Social Work in Health Care expressed standards for social workers considered that some of them are (Sajjad Majidi Parast1 and Behrouz Allaii2,2014):

- Ethics and Values

- Health inequalities

- Cultural Competence

- Privacy professionals (Journal of Social Science for Policy Implications ,2014)

- Assessment

- Intervention and Treatment

- Leadership in social work

- File Management

- Crisis Intervention

- Empowerment Most of these standards, the role of social work in the health care system has been investigated. Therefore, according to this definition, a one-dimensional view of the patient and the patient is almost obsolete.

Social work Skills

In dealing with the multitude of problems that social workers address, they must employ a variety of skills depending on the job that needs to get done. While some of these skills may be natural, many of them are honed while a social worker earns his or her bachelor's or master's degree. Below is a list of traits that a well-trained social worker.

- Active Listening - Giving full attention to what other people are saying, taking time to understand the points being made, asking questions as appropriate, and not interrupting at inappropriate times.

- Social Perceptiveness - Being aware of others' reactions and understanding why they react as they do.

- Speaking - Talking to others to convey information effectively.

- Critical Thinking - Using logic and reasoning to identify the strengths and weaknesses of alternative solutions, conclusions or approaches to problems.

- Coordination - Adjusting actions about others' actions.

- Reading Comprehension - Understanding written sentences and paragraphs in work-related documents.

- Service Orientation - Actively looking for ways to help people.

- Writing - Communicating effectively in writing as appropriate for the needs of the audience.

- Complex Problem Solving - Identifying complex problems and reviewing related information to develop and evaluate options and implement solutions.

- Judgment and Decision Making - Considering the relative costs and benefits of potential actions to choose the most appropriate one. (s.rengasamy 2009), (school of social work 2019)

The activities described in these words are intellectual, not mechanical, not routine in character. The worker must possess fine powers of analysis and discrimination, breadth and flexibility of sympathy, sound judgment, skill in utilizing whatever resources are available, facility in devising new combinations. These operations are assured of intellectual quality (Abraham Flexner 2010

\section{The objectives in the field of health care}

in general, it is the specific mode and influenced policy, attitudes, ideologies, values, and scholars in this field. But the concept of social work intervention aims to improve the social functioning of the health care so the goals and roles of social work might be expected to perform include ( N A S W,2002):

- Counseling groups or individuals in dealing with chronic illness, loss of a loved one or substance abuse

- Being a mandatory reporter and investigator of potential child abuse

- Assess the needs of each client and keep detail records of clients progress in the healing process 
- Advocate on behalf of the client or family members by consulting with other members of the healthcare team

- Helping to connect clients with community and government resources around financial or insurance issues

- Help clients fill out Medicare or Medicaid application information and oversee their information and status of ongoing benefits.

- Evaluation of stress on the psychological, social, emotional and physical environment for patients and their families may encounter and assist them directly.

- Play the role of counselor, advocate, liaison, mediation and helping patients to make optimal use of health care programs.

- Providing health care programs, including prevention programs and improving the quality of life in a way that is applicable and accessible to all patients and members of the community.(Sajjad Majidi Parast1 and Behrouz Allaii, 2014)

- Create interaction and communication between health care personnel and patients treated with the positive cooperation between them is obtained.

- Participation and correct analysis of health policy and planning (a member of making macro policy committee).

- Leadership programs in the areas of participation and patient education.

- Management and evaluation of how to provide health services to the poor through research.

- Changing health care services from the service center to need a center and the combination of the two.

- Working with the mentally ill, frail and their families and assess their needs.

- Identify the main causes of mental illnesses and other diseases by providing community-based rehabilitation.

\section{Epidemic diseases}

A communicable (or infectious) disease is an illness due to the transmission of a specific infectious agent (or its toxic products) from an infected person, animal or inanimate source to a susceptible host, either directly or indirectly.

A commonly used definition of an epidemic is that of Abram Benenson, who defined it as 'the occurrence in a community or region of cases of illness (or an outbreak) with a frequency clearly in excess of normal expectancy'. The meaning of the term epidemic is broad. The numbers of cases, geographic extent, and time period need to be specified to be able to describe an epidemic . . (Charles Guest, Feb 2013). IPCE ,WHO, 2014

\section{How can we prevent epidemics?}

Classically, prevention is described as primary, secondary, or tertiary.

Primary prevention: preventing disease onset In the context of communicable diseases various options include:

- Eliminating the organism:

- controlling organisms in their natural reservoir

- Environmental protection: ensuring a safe drinking water supply, with proper separation of sewage from drinking water .

- safeguarding the food supply.

- Interrupting the chain of transmission

- modifying behavior,

- personal hygiene - a simple yet effective means of control

- Reducing susceptibility in the host: 
- reversing malnutrition and micronutrient deficiency to boost people's immunity in low-income countries helps to prevent the spread of, for example, tuberculosis

- vaccination - perhaps the most successful example of primary prevention, leading to global eradication of smallpox and to a sustained reduction in the incidence and consequences of childhood diseases.

- Health education and community participation:

- promoting vector control programmers, in particular the use of personal protection like insect repellents and mosquito nets

- supporting personal hygiene and food hygiene measures in preventing gastroenteritis

- endorsing vaccination campaigns.

\section{Secondary prevention: arresting the progression of established disease}

- The options here include:

- Screening: where there is an asymptomatic or pre-symptomatic period in the infection process screening programmes are useful.

- Outbreak/epidemic investigation.

- The main aims of epidemic/outbreak investigation are to:

- identify the causative agent, route of transmission, and risk factors for the outbreak

- develop and implement control and prevention strategies and provide advice to prevent a similar event in the future.

\section{Tertiary prevention: limiting the consequences of established disease}

- One example of this is providing artificial limbs for a child who has needed amputations following severe meningococcal septicaemia . (Charles Guest, Feb 2013). IPCE ,WHO, 2014

\section{Method}

This is an analytical community-based cross-sectional study that was conducted in Jazan region, kingdom of Saudi Arabia. Different rural and urban areas in the region were covered, to social worker staff enrolled in the hospitals in jazan region employees. All were Saudis, they are employer 25-+45years. The study was conducted during April -July 2020 by researcher

A non-probability convenient sample was used to reach a total of (102) males and females individuals and the total of social worker in jazan hospitals (125) and (23) social worker nonresponse. A self-administrated structured pre-coded questionnaire was developed, tested, and used for data collection. It was selfadministered by respondents. The questionnaire was composed of three sections; socio-demographic background, a. social workers' knowledge of epidemic diseases. and the preventive role of social workers in raising awareness of preventive diseases. Study accomplishment was approved and stamped by the university research unit and respondents' consent was assured before data collection.

Data analysis was processed with the use of Statistical Package for Social Sciences (SPSS V. 24). Descriptive statistics and bilateral relations were generated Correlations were calculated by testing the Chisquare ,Mean Std app. Deviation Ratio, T-Test, Spearman's . Identify the extent of the specialist's knowledge of the nature of epidemic diseases and determine the actual preventive role of social workers in raising awareness of preventive diseases .The significance of the difference was achieved at $\mathrm{P}<0.05$ and odds ratios, and charts and tables were produced by Microsoft Excel .

\section{Limitations}

Our analysis is not without limitations. As with any study using self-reports to measure potentially sensitive topics, our survey is susceptible to social desirability bias. It is possible, may have over-reported compliance with government-mandated restrictions. While we cannot eliminate this possibility altogether, respondents were repeatedly reassured of the confidentiality of their responses, and were given the option of skipping any question they preferred not to answer. Pre-testing suggested that our questions were not perceived as particularly sensitive, which is consistent with the many affirmative responses we received to questions about non-compliance 


\section{Results}

The questionnaire has been applied upon(102) the social worker They work in the Ministry of Health in Jizan Region. Within the time limits for research, it has been applied in 2020. Within the spatial limits, of Jazan Region .

\section{1- The socio-demographic background of the study(N 102)}

\begin{tabular}{|c|c|c|c|}
\hline variables & Categories & Frequency & Percent \\
\hline \multirow[b]{6}{*}{ Age } & $25-30$ & 2 & $2 \%$ \\
\hline & $30-35$ & 4 & $3.90 \%$ \\
\hline & $35-40$ & 40 & $39.20 \%$ \\
\hline & $40-45$ & 36 & $35.30 \%$ \\
\hline & $<45$ & 20 & $19.60 \%$ \\
\hline & Total & 102 & $100 \%$ \\
\hline \multirow[b]{3}{*}{ Sex } & male & 42 & $41.20 \%$ \\
\hline & Female & 60 & $58.80 \%$ \\
\hline & Total & 102 & $100 \%$ \\
\hline \multirow[b]{4}{*}{ Marital status } & signal & 12 & $11.80 \%$ \\
\hline & married & 84 & $82.80 \%$ \\
\hline & other & 6 & $5.90 \%$ \\
\hline & Total & 102 & $100 \%$ \\
\hline \multirow[b]{3}{*}{ Residence } & Rural & 17 & $16.70 \%$ \\
\hline & Urban & 85 & $83.30 \%$ \\
\hline & Total & 102 & $100 \%$ \\
\hline \multirow[b]{5}{*}{ Experience } & $>5$ & 22 & $35.30 \%$ \\
\hline & $05-10$ & 20 & $21.60 \%$ \\
\hline & $010-15$ & 36 & $19.60 \%$ \\
\hline & $<15$ & 20 & $3.90 \%$ \\
\hline & Total & 102 & $19.60 \%$ \\
\hline
\end{tabular}

Table [1] Shows the distribution of socio-demographic background by age, of the total, reported (102) respondents; 40 (39.2\%) were age between 35- 40; Only 2 (27\%) respondents were age between 25-30., the distribution of socio-demographic background by six, $42(41.2 \%)$ were male between 35-40, Only 60 (58.8\%) respondents were female, the distribution of socio-demographic by Residence background by Residence, 17 (16.7\%) were Rural, Only 85 (83.3\%) respondents were Urban and the distribution of sociodemographic background by Experience 36 (35.3\%) were 10-15 years, Only 4(3.9\%) respondents were less than 5 years.

2. The extent of the social workers knowledge of the epidemic diseases(N 102)

$$
\text { sentence }
$$

\begin{tabular}{|l|l|l|}
\hline \multicolumn{3}{|l|}{ Frequencies } \\
\hline Yes & Sort & No \\
\hline
\end{tabular}

Total weights

Mean

Std.

percent $\quad$ Rank 


\begin{tabular}{|c|c|c|c|c|c|c|c|c|c|}
\hline & & & of & & & & & & \\
\hline 1 & $\begin{array}{l}\text { I wear the importance the } \\
\text { factors that help spread } \\
\text { epidemic diseases }\end{array}$ & 12 & 90 & 0 & 294 & 2.88 & 0.324 & $96.10 \%$ & 1 \\
\hline 2 & $\begin{array}{l}\text { I know the diseases spread } \\
\text { in the region }\end{array}$ & 12 & 82 & 8 & 278 & 2.73 & 0.6 & $90.80 \%$ & 3 \\
\hline 3 & $\begin{array}{l}\text { Understand the causes that } \\
\text { lead to positive or negative } \\
\text { health and behavior } \\
\text { outcomes }\end{array}$ & 24 & 74 & 4 & 274 & 2.69 & 0.545 & $89.50 \%$ & 4 \\
\hline 4 & $\begin{array}{l}\text { I know about the prevailing } \\
\text { epidemic diseases in the } \\
\text { region }\end{array}$ & 20 & 82 & 0 & 286 & 2.8 & 0.399 & $93.50 \%$ & 2 \\
\hline 5 & $\begin{array}{l}\text { I know the factors that help } \\
\text { spread epidemic diseases }\end{array}$ & 16 & 78 & 8 & 274 & 2.69 & 0.613 & $89.50 \%$ & 4 \\
\hline 6 & $\begin{array}{l}\text { I know that the proper use of } \\
\text { the material resources } \\
\text { necessary to raise awareness } \\
\text { of epidemic diseases }\end{array}$ & 22 & 72 & 8 & 268 & 2.63 & 0.628 & $87.60 \%$ & 6 \\
\hline 7 & $\begin{array}{l}\text { Aware that program/policy } \\
\text { changes important to have } \\
\text { been made to access to } \\
\text { health services }\end{array}$ & 26 & 66 & 10 & 260 & 2.55 & 0.669 & $85.00 \%$ & 7 \\
\hline 8 & $\begin{array}{l}\text { I don't understand the social } \\
\text { determinants of health }\end{array}$ & 22 & 74 & 6 & 272 & 2.67 & 0.586 & $88.90 \%$ & 5 \\
\hline 9 & $\begin{array}{l}\text { Sure dealing with epidemic } \\
\text { diseases needs to scientific } \\
\text { models and theories in all } \\
\text { stages }\end{array}$ & 16 & 80 & 6 & 278 & 2.73 & 0.566 & $90.80 \%$ & 3 \\
\hline 10 & $\begin{array}{l}\text { I know the importance of } \\
\text { developing a preventive } \\
\text { policy for social service in } \\
\text { the medical field }\end{array}$ & 22 & 74 & 6 & 272 & 2.67 & 0.586 & $88.90 \%$ & 5 \\
\hline & total & \#\# & 842 & 64 & 3022 & 29.6 & 3.194 & $89.70 \%$ & \\
\hline
\end{tabular}

Table [2] Shows the extent of the social workers knowledge of the epidemic diseases It is clear from the previous table that the percentage $(96.10 \%)$ to sentence (I wear the importance the factors that help spread epidemic diseases), and (i know about the prevailing epidemic diseases in the region) it occupies the second place where it scored (93.5\%), while the social worker sees that (I know that the proper use of the material resources necessary to raise awareness of epidemic diseases) recorded the order before the last sentence $(87.6 \%)$ and the phrase (Aware that program/policy changes important to have been made to access to health services) the means to achieve recorded the last order $(85 \%)$ with total Mean and stand deviation of dimension 29.6), (3.194) respectively. and the total weights and percentage of the dimension (3022), 
$(89.70 \%)$ respectively, the study noted that most the phrases of that axis were limited in its results to the high level which means that the study sample (social workers) has knowledge about the epidemic diseases .

3. Determine the actual preventive role of social workers in raising awareness of preventive diseases . ( N 102)

\begin{tabular}{|c|c|c|c|c|c|c|c|c|c|}
\hline & \multirow[t]{2}{*}{ sentence } & \multicolumn{3}{|c|}{ Frequencies } & \multirow{2}{*}{$\begin{array}{l}\text { Total } \\
\text { weights }\end{array}$} & \multirow[t]{2}{*}{ Mean } & \multirow{2}{*}{$\begin{array}{l}\text { Std. } \\
\text { Deviation }\end{array}$} & \multirow[t]{2}{*}{ percent } & \multirow[t]{2}{*}{ Rank } \\
\hline & & Yes & $\begin{array}{l}\text { Sort } \\
\text { of }\end{array}$ & No & & & & & \\
\hline 1 & $\begin{array}{l}\text { Follow methods to prevent epidemic } \\
\text { diseases while working }\end{array}$ & 24 & 62 & 16 & 250 & 2.45 & 0.753 & $81.70 \%$ & 8 \\
\hline 2 & $\begin{array}{l}\text { Helping patients to restore balance in } \\
\text { personal, family and social life }\end{array}$ & 14 & 88 & 0 & 292 & 2.86 & 0.346 & $95.40 \%$ & 1 \\
\hline 3 & $\begin{array}{l}\text { I participate in designing studies to assess } \\
\text { the effects of preventive interventions }\end{array}$ & 36 & 28 & 38 & 194 & 1.9 & 0.802 & $63.40 \%$ & 11 \\
\hline 4 & $\begin{array}{l}\text { I participate in crisis management and } \\
\text { natural disasters }\end{array}$ & 42 & 50 & 10 & 244 & 2.39 & 0.662 & $79.70 \%$ & 9 \\
\hline 5 & $\begin{array}{l}\text { I do not have a community outreach plan } \\
\text { for ways to deal with epidemic diseases }\end{array}$ & 44 & 46 & 12 & 238 & 1.67 & 0.68 & $55.60 \%$ & 10 \\
\hline 6 & $\begin{array}{l}\text { I participate in educating the community } \\
\text { about preventive precautions }\end{array}$ & 28 & 70 & 4 & 270 & 2.65 & 0.557 & $88.20 \%$ & 4 \\
\hline 7 & $\begin{array}{l}\text { Provide information about issues that can } \\
\text { be effective in making decisions about } \\
\text { health }\end{array}$ & 30 & 68 & 4 & 268 & 2.63 & 0.561 & $87.60 \%$ & 6 \\
\hline 8 & $\begin{array}{l}\text { I encourage individuals to change their } \\
\text { behaviors related to the social aspects } \\
\text { associated with health }\end{array}$ & 26 & 74 & 2 & 276 & 2.71 & 0.499 & $90.20 \%$ & 3 \\
\hline 9 & $\begin{array}{l}\text { I seek to change the behavior of } \\
\text { beneficiaries to precautionary measures } \\
\text { to improve the quality of life }\end{array}$ & 16 & 84 & 2 & 286 & 2.8 & 0.446 & $93.50 \%$ & 2 \\
\hline 10 & $\begin{array}{l}\text { I seek to discover systemic factors that } \\
\text { prevent or discourage access to services }\end{array}$ & 33 & 67 & 2 & 269 & 2.64 & 0.523 & $87.90 \%$ & 5 \\
\hline 11 & $\begin{array}{l}\text { I participate in the activation of } \\
\text { international days within the community }\end{array}$ & 34 & 64 & 4 & 264 & 2.59 & 0.569 & $86.30 \%$ & 7 \\
\hline 12 & $\begin{array}{l}\text { I Implement the programs according to } \\
\text { specific objectives and evaluate the means } \\
\text { to achieve }\end{array}$ & 34 & 44 & 24 & 224 & 1.8 & 0.797 & $60.10 \%$ & 12 \\
\hline & Total & 401 & 791 & 134 & 3309 & 32.4 & 2.804 & $83.20 \%$ & \\
\hline
\end{tabular}

Table [3] Shows the actual preventive role of social workers in raising awareness of preventive diseases, It is clear from the previous table that the percentage (95.40\%) to sentence (helping patients to restore balance in personal, family and social life ) and ( I seek to change the behavior of beneficiaries to precautionary measures to improve the quality of life) it occupies the second place where it scored (93.50\%), while the study sample sees that (participation in designing studies to assess the effects of preventive interventions) recorded the order before the last sentence $(63.40 \%$ ) and the sentence (I Implement the programs according to specific objectives and evaluate the means to achieve) recorded the last order $(60.10 \%)$ with total Mean and stand deviation of dimension (32.44), (2.804) respectively. and the total weights and percentage of the dimension (3309), (83.2\%), the study noted that most the phrases of that axis were limited in its results to the middle and high level which means that the study sample (social workers) has practice preventive role to raising awareness of preventive diseases .

4. Relationship Between socio-demographic background and dimensions of the study . (N 102)

\begin{tabular}{|l|l|l|l|l|l|}
\hline & \multicolumn{4}{|c|}{ Independent Samples Test ( 2 groups) } \\
\hline & Dimension & Variances & t & df & $\begin{array}{l}\text { Sig.(2- } \\
\text { tailed) }\end{array}$ \\
\hline
\end{tabular}




\begin{tabular}{|c|c|c|c|c|c|}
\hline \multirow{4}{*}{ שֶ } & \multirow{2}{*}{$\begin{array}{l}\text { The extent of the social workers } \\
\text { knowledge of the epidemic } \\
\text { diseases }\end{array}$} & $\begin{array}{l}\text { Equal } \\
\text { assumed }\end{array}$ & -1.009 & 100 & 0.315 \\
\hline & & $\begin{array}{l}\text { Equal variances not } \\
\text { assumed }\end{array}$ & -0.951 & 68.91 & 0.345 \\
\hline & \multirow{2}{*}{$\begin{array}{l}\text { Determine the actual preventive } \\
\text { role of social workers in raising } \\
\text { awareness of preventive diseases }\end{array}$} & $\begin{array}{ll}\begin{array}{l}\text { Equal } \\
\text { assumed }\end{array} & \text { variances } \\
\end{array}$ & -0.022 & 100 & 0.982 \\
\hline & & $\begin{array}{l}\text { Equal variances not } \\
\text { assumed }\end{array}$ & -0.022 & 76.65 & 0.983 \\
\hline \multirow[t]{2}{*}{ 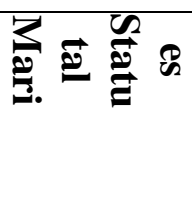 } & \multirow{2}{*}{$\begin{array}{l}\text { The extent of the social workers } \\
\text { knowledge of the epidemic } \\
\text { diseases }\end{array}$} & $\begin{array}{ll}\text { Equal } & \text { variances } \\
\text { assumed } & \end{array}$ & 0.13 & 100 & 0.9 \\
\hline & & $\begin{array}{l}\text { Equal variances not } \\
\text { assumed }\end{array}$ & 0.1 & 12.68 & 0.92 \\
\hline \multirow{6}{*}{ 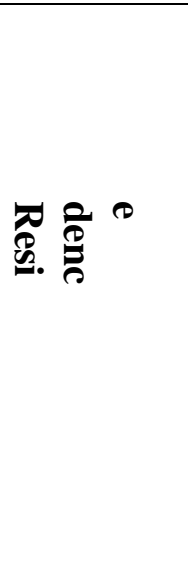 } & \multirow{2}{*}{$\begin{array}{l}\text { Determine the actual preventive } \\
\text { role of social workers in raising } \\
\text { awareness of preventive diseases }\end{array}$} & $\begin{array}{ll}\text { Equal } & \text { variances } \\
\text { assumed } & \end{array}$ & -0.05 & 100 & 0.96 \\
\hline & & $\begin{array}{l}\text { Equal variances not } \\
\text { assumed }\end{array}$ & -0.04 & 12.75 & 0.97 \\
\hline & \multirow{2}{*}{$\begin{array}{l}\text { The extent of the social workers } \\
\text { knowledge of the epidemic } \\
\text { diseases }\end{array}$} & $\begin{array}{ll}\text { Equal } & \text { variances } \\
\text { assumed } & \\
\end{array}$ & -1.27 & 100 & 0.21 \\
\hline & & $\begin{array}{l}\text { Equal variances not } \\
\text { assumed }\end{array}$ & -1.09 & 20.21 & 0.29 \\
\hline & \multirow{2}{*}{$\begin{array}{l}\text { Determine the actual preventive } \\
\text { role of social workers in raising } \\
\text { awareness of preventive diseases }\end{array}$} & $\begin{array}{ll}\text { Equal } & \text { variances } \\
\text { assumed } & \end{array}$ & -0.39 & 100 & 0.7 \\
\hline & & $\begin{array}{l}\text { Equal variances not } \\
\text { assumed }\end{array}$ & -0.33 & 20.2 & 0.74 \\
\hline
\end{tabular}

Table [4] $\mathrm{T}$ value is insignificant at the 0.05 level (2-tailed) (sex ,marital statues and residence) .

\section{Conclusion}

Social workers play an important role in raising individual and community awareness of epidemic diseases and ways to prevent them as one of the goals of the medical social work, So social workers need to be able to collect, understand, and use epidemiological data to identify risk and protective factors to help guide decision making about where to focus and on what to focus preventive efforts in their communities. Social workers also need to understand and use the standards of evidence required inadequate trials of the efficacy of preventive interventions.

\section{Recommendation}

According to the results presented can be used to improve the quality of services to patients, families, and communities aimed at the following suggestions are offered:

- The social workers in the health care system can play the role of the researcher in finding the detection of epidemic diseases and patient needs.

- Social workers in the health care system can make major decisions regarding the type of services and enhance patient satisfaction.

- To avoid increasing the level of diseases in the community, social workers should help to improve the structures and institutions of society, scientific planning and management should be considered.

- For preventing the epidemic diseases in society, we will require the cooperation of all agencies and governmental and nongovernmental organizations (NGOs).

- $\quad$ Support all hospitals with professional social workers. 
[1] Abraham Flexner : Is Social Work a Profession? , RESEARCH ON SOCIAL WORK PRACTICE, General Education $\quad$ Board, New $\quad$ York $\quad$ City 2010 file:///C:/Users/amal/Downloads/Is_Socialwork_a_Profession(Flexner)\%20(2).

[2] Al Khatib A. Impact of globilization on the group-purchasing program of pharmaceutical and medical supplies by the GCC states. Paper presented at 11th International Conference on The Impact of Globalization on Development and Health Care services in Islamic Countries, Kuwait, 23-27 March, 2002.

[3] Albee GW. Psychopathology, prevention and the just society. Journal of Primary Prevention. 1983.

[4] Betty J. Ruth, MSW, MPH, Esther E. Velásquez, MSW, MPH, [...], and Dory Ziperstein, MSW, MPH , 2016 .https://www.ncbi.nlm.nih.gov/pmc/articles/PMC4888782/

[5] Cohen L, Chavez V, Chehimi S, editors. Prevention is primary: Strategies for community wellbeing. 2. San Francisco: Jossey-Bass; 2010.

[6] Charles Guest, Walter Ricciardi, Ichiro Kawachi, and Iain Lang :Oxford Handbook of Public Health Practice (3 edn), Feb 2013.

[7] Galea S, Tracy M, Hoggatt KJ, DiMaggio C, Karpati A. Estimated deaths attributable to social factors in the United States. American Journal of Public Health. 2011;101(8):1456-1465. [PMC free article] [PubMed] [Google Scholar]

[8] Harlow: Pearson NASW Standards for Clinical Social Work Practice, UK, Longman, (2005). https://www.socialworkers.org/practice/NASWClinicalSWStandards.pdf Website of Wikipedia(2008). Available at: en.wikipedia.org/wiki/Health_care Website of Ministry of Health .

[9] Hutchison .E.: Social Work Defined. National Association of Social Workers., Dimensions of Human Behavior Person and Environment. London, Sage(2008).

[10] infection Prevention and Control of Epidemic- and Pandemic-Prone Acute Respiratory Infections in Health Care, WHO, 2014

[11] Journal of Social Science for Policy Implications June 2014, Vol. 2, No. 2, ,American Research Institute for Policy Development 2014. .

[12] Munoz, R. F., Mrazek, P. J., \& Haggerty, R. J. (1996). Institute of Medicine report on prevention of mental disorders: summary and commentary. American Psychologist, 51(11), 1116.

[13] Reading material for MSW students prepared by S.Rengasamy to supplement clssroom teaching .https://www.scribd.com/doc/14767491/Introduction-to-Professional-Social-Work and School of Social Work : university of Buffalo,2019 .http://socialwork.buffalo.edu/admissions/is-social-work-right-career-for-me/list-of-essentialskills-in-social-work.html

[14] Sajjad Majidi Parast1 and Behrouz :The Role of Social Work in Health Care System Journal of Social Science for Policy Implications June, American Research Institute for Policy Development , Vol. 2,2014. Allaii2https://jsspi.com/journals/jsspi/Vol 2 No 2 June 2014/4.pdf

[15] Samadi Rad, Anvar.:social work in Iran. Kayhan 25/04/2008. Samadi Rad, Anvar. (2012).

[16] Tehran. Wilson K, Ruch G, Lymbery M: Retraining of social workers employed in health care., Cooper A (2008) .

[17] The World Factbook. 2013 Available at https://www.cia.gov/library/publications/the-worldfactbook/ 